\title{
Innovative Research of Education and Management's Mode for College Students of post-90s_-Based on a survey of six colleges and universities in Fuzhou
}

\author{
Tang Shan \\ Institute of Technology, Southwest Petroleum University, Sichuan, Nanchong, China \\ Tangshan008@163.com
}

\begin{abstract}
Keywords: college student of post-90s, education and management, innovation
\end{abstract}
\begin{abstract}
Education and management's mode plays a vital role in college students' educational work, so, it is necessary to explore a new mode of education and management to adapt to the new era's college students. Based on analysis the shortcomings of traditional education and management and according to the survey results of six colleges and universities in Fuzhou ,this paper proposes seven new terms of education and management's modes and ffinally introduces a new model of harmonious management,so as to provide method references to solve the problem of education and management for the college students of post-90s.
\end{abstract}

\section{Introduction}

The college students are the post-90s.The characteristic of the post-1990 freshman is independence of thought and personalized publicity. And the philosophy, world view and value is easy to be influenced by multiple network culture. And they have evident negative mentality for traditional didactic educational management way, which brings challenges for the educational management of the college students.

\section{Status of Education Management of the Post-90s College Students}

In order to fully know about the status of education management of the post-90s, the writer uses questionnaire method and issued 600 questionnaires to the instructors and students in six colleges in Fuzhou by using network and paper questionnaire. There are 522 effective questionnaires being actually recycled, and the effective rate of questionnaires is $87 \%$. The distribution objects of the questionnaires include the first-rank, the second-rank and technical colleges. It not only includes the instructors, but also includes the post-90s college students, which ensures the representation of samples. The questionnaire distribution is shown in Table 1.

Table 1 Questionnaire distribution about student management modes of six colleges in Fuzhou

\begin{tabular}{|c|c|c|c|c|c|c|}
\hline Colleges & $\begin{array}{c}\text { Fuzhou } \\
\text { University }\end{array}$ & $\begin{array}{c}\text { Fujian } \\
\text { Normal } \\
\text { University }\end{array}$ & $\begin{array}{c}\text { Fujian } \\
\text { Agricultur } \\
\text { e and } \\
\text { Forestry } \\
\text { University }\end{array}$ & $\begin{array}{c}\text { Fujian } \\
\text { Jiangxia } \\
\text { University }\end{array}$ & $\begin{array}{c}\text { Fuzhou } \\
\text { Education } \\
\text { College }\end{array}$ & $\begin{array}{c}\text { Fuzhou } \\
\text { Software } \\
\text { Professional } \\
\text { Technology } \\
\text { College }\end{array}$ \\
\hline
\end{tabular}

\begin{tabular}{lllllll}
\hline Instructors & & & & & \\
\hline Students & 70 & 75 & 75 & 90 & 85 & 85 \\
\hline Aggregation & 100 & 100 & 100 & 100 & 100 & 100 \\
\hline
\end{tabular}

According to the feedback of questionnaires, through the refinement analysis, the paper gets the following problems.

The colleges still adhere to traditional education management concept, and still apply full responsibility of instructors for the subject of education management (accounting for 92\%), which doesn't fully mobilize teacher resources and parents resource to establish all-member training 
pattern.

The education management mode still applies self-management with students or committee as the principal part (accounting for 86\%), which ignores the influence of elective course of credit system and the weakening of class concept. Traditional organization is more and more weak for mobilizing the enthusiasm of students.

The content of education management is gradually developed into dealing with the tasks arranged by the school organizations. The moral education of students is weakened. Educational guidance only depends on classroom teaching (accounting for 83\%), and the content is boring and the form is single, and the unhealthy customs of network prevails, which has great impact on the shaping of values of the post-90s.

The education management means still applies persuasive education and penalty education of instructors (accounting for 71\%). The education method is easy to arouse the inimical emotion of the post-90s college students, which cant achieve the objective of education. The incentive method is concentrated on assessment qualification or moral education points (accounting for 88\%), which deviates the aim of moral education.

For the characteristics of the post-90s college students, the colleges achieve the objective of deep moral education by management and service, which must reform traditional education mode and innovate management mode.

\section{Analysis on New Education Management Mode of the Post-90s College Students}

(1) Implementing tutorial management mode and constructing educational atmosphere of colleges. Making students and teachers participate in college education management and applying the ways of communication, coordination and participation can establish a new education management mode, school management_-multiple participation [1], which is good for fully constructing all-member cultivating atmosphere of teacher-student interaction, research interaction and teaching interaction. In order to ensure the effectiveness of tutorial system, the colleges should set up the reward mechanism according to the actuality. And the colleges should summarize good experience to ensure the institutionalization of tutorial system.

(2) Promoting dormitory management mode and implementing the management like the apartment house. At present, the colleges generally implement the credit system. Under the credit system, the students select the courses freely. Different teachers takes charge of the same class and the same course, which makes the original major and the concept of classes and grades desalted. And it promotes that the student education management must find and establish new platform. The investigation data shows that $86 \%$ of investigators think that the organizational form of the colleges still uses the grade and class as the subject, which makes the working efficiency low.

(3) Combining student management and party construction, and using part construction for management. For party construction, $74 \%$ of participators choose that the party construction of colleges generally applies coping way, and develop the party member in order to achieve the party member development indicator. The party construction doesn't have important influence in the heart of students. So the colleges can combine party construction, moral education and student work, and uses party construction for promoting management.

For moral education function, in order to be admitted to the party, the activists not only need to meet the necessary requirements of joining the party, but also requires to do good things for the students with difficulties. And the feedback rate of department and class should be more than $50 \%$.

For student management, apartment party branch can be established in the apartment of students as daily supervision and service department. The members of apartment party branch committee participate in the inspection and estimation of dormitories. To join the party, the members of dormitories and student leaders must make apartment party branch write review opinions and set up student leader demonstration, which makes the student party members and student leaders combine with the students with difficult in study, life and psychology, and plays the role of student party members in education [2]. The performance of student leaders is quantitatively 
ordered as the important reference of joining the party. In order to expand the influence of party construction, the advanced students can be praised by posting inventories and setting up examples. Using party construction to promote management not only can effectively regulating the motivations of student, but also ensures the implementation of developing party members.

\section{Deep Thinking}

For management method, the famous manager, You Ximin, proposed the concept of harmonious management in Harmonious Management Theory, and made the further explanation, which means to uses the psychology and behavior measures to form an atmosphere to induce the behavior agent act out the expected behavior of organizations. Meanwhile, the certain factors of the organizations and the certain relationship is optimized such as structure design, system arrangement and process improvement [6]. For the education management of the post-90s college students, the writer thinks that with the help of the concept of harmonious management, the colleges can take the following measures. For the management objects or the students, the colleges establish the atmosphere of mutual trust between teacher and students, motivate the initiative of students according to the characteristics of different students, and rationally guide the students to participate in management. On the other hand, for the management institutions or organization level, the organization level of students should be improved, and the resources in school and out of school should be coordinated to promote the management of students., which has great reference significance for establishing harmonious campus management mode. The management concept is the next research direction of college education managers.

For the education management of the post-1990s, the colleges should set up the education concept of student-based idea, develop the working thought, and innovate the education and guidance method to improve the quality and level of education management of college students.

\section{References:}

[1] Wang Jianfu, He Zhengying, Participation management of college students [J], Party Construction and Moral Education of Colleges, 2012, (1): 58-59.

[2] Fan Huanqian, Guo Honglian, Establishment of seven-level working system of education management in colleges [J], Journal of Fujian Agricultural and Forestry University (Philosophy and Social Science Edition), 2010,13 (1): 101-103.

[3] Bi Shengjie, Wang Yan, Kan Ying, Effective ways of enhancing education management of the freshmen [J], Navigation Education Research, 2012, (1): 105-108.

[4] Hu Jing, Guo Shaoqing, Fu Guoliang, Exploration on countermeasures of education management of college students [J], Science and Technology Information, 2011, (32): 30-31.

[5] Sun Yanhuai, Application of motivation theory in education management of college students [J], China Youth Research, 2008, (11)99-102.

[6] Xi Youmin, Han Wei, Ge Jing, Research of harmonious management theory [M], Xi'an, Xi'an Jiaotong University Press, 2006. 